\title{
Aulactinia vladimiri, a new species of sea anemone (Actiniaria: Actiniidae) from Kamchatka waters, North-West Pacific
}

\author{
N.P. Sanamyan ${ }^{1}$, K.E. Sanamyan ${ }^{1,3}$, E.S. Bocharova ${ }^{2}$ \\ ${ }^{1}$ Kamchatka Branch of Pacific Geographical Institute, Far-Eastern Branch of the Russian Academy \\ of Sciences, Partizanskaya 6, Petropavlovsk-Kamchatsky, 683000, Russia. \\ e-mail: actiniaria@sanamyan.com \\ ${ }^{2}$ Russian Federal Research Institute of Fisheries and Oceanography (VNIRO), V. Krasnoselskaya \\ 17, Moscow, 107140, Russia \\ e-mail: bocharova.ekaterina@gmail.com \\ ${ }^{3}$ Corresponding author
}

\begin{abstract}
Aulactinia vladimiri sp.n. is a small sea anemone described from shallow waters in vicinity of Petropavlovsk-Kamchatsky (Pacific coasts of Russia). The species has 48 (in fully developed specimens) tentacles which are usually bright pink. In contrast with internally brooding A. stella (Verrill, 1864), A. incubans Dunn, Chia et Levine, 1980 and A. vancouverensis Sanamyan, Sanamyan et McDaniel, 2013 (three species of the genus reported for North Pacific), the eggs of $A$. vladimiri sp.n. are incubated in an external brood chamber. The phylogenetic analysis for $A$. vladimiri sp.n. showed that $A$. stella is the closest related species with obtained sequences of mitochondrial genes 12S rRNA,16S rRNA and cytochrome oxidase III.

How to cite this article: Sanamyan N.P., Sanamyan K.E., Bocharova E.S. 2015. Aulactinia vladimiri, a new species of sea anemone (Actiniaria: Actiniidae) from Kamchatka waters, North-West Pacific // Invert. Zool. Vol.12. No.2. P.117-130. doi: 10.15298/invertzool.12.2.01
\end{abstract}

KEY WORDS: Sea anemone, Actiniaria, North Pacific, Kamchatka, Aulactinia, brood chamber, mitochondrial gene, phylogenetic analysis.

\section{Aulactinia vladimiri - новый вид актиний (Actiniaria: Actiniidae) из прикамчатских вод северо-западной Пацифики}

\footnotetext{
Н.П. Санамян ${ }^{1}$, К.Э. Санамян ${ }^{1}$, Е.С. Бочарова ${ }^{2}$

${ }^{1}$ Камчатский филиал Тихоокеанского института географии ДВО РАН, ул. Партизанская, 6, Петропавловск-Камчатский 683000, Россия.

e-mail: actiniaria@sanamyan.com

${ }^{2}$ Всероссийский научно-исследовательский институт рыбного хозяйства и океанографии (ВНИРО), ул. В. Красносельская, 17, Москва,107140, Россия

e-mail: bocharova.ekaterina@gmail.com
}

РЕЗЮМЕ: Aulactinia vladimiri sp.n. найдена на мелководье у ПетропавловскаКамчатского (тихоокеанское побережье России). Вид характеризуется наличием у 
полностью развитых экземпляров 48 щупалец, которые обычно окрашены в яркорозовый цвет. В отличие от $A$. stella (Verrill, 1864), A. incubans Dunn, Chia et Levine, 1980 и A. vancouverensis Sanamyan, Sanamyan et McDaniel, 2013 (три вида рода, указанные для северной части Пацифики), у которых яйца и эмбрионы инкубируются в полости тела, у A. vladimiri sp.n. они инкубируются во внешней выводковой камере. Филогенетический анализ показал, что для A. vladimiri sp.n. ближайшим родственным видом, для которого известны последовательности митохондриальных генов $12 \mathrm{~S}$ pРНК, 16S рРНК и цитохром-оксидазы III, является A. stella.

Как цитировать эту статью: Sanamyan N.P., Sanamyan K.E., Bocharova E.S. 2015. Aulactinia vladimiri, a new species of sea anemone (Actiniaria: Actiniidae) from Kamchatka waters, North-West Pacific // Invert. Zool. Vol.12. No.2. P.117-130. doi: 10.15298/ invertzool.12.2.01

КЛЮЧЕВЫЕ СЛОВА: морские анемоны, актинии, Actiniaria, северная Пацифика, Камчатка, Aulactinia, выводковая камера, митохондриальный ген, филогенетический анализ.

\section{Introduction}

The fauna of shallow water sea anemones inhabiting Avacha Bay and neighboring waters is relatively well known and comprises 16 species (Sanamyan, Sanamyan, 2009, 2010). In the present paper we provide detailed description of the species briefly described as Aulactinia sp. by Sanamyan, Sanamyan (2010). The first specimen of this small sea anemone was observed by $\mathrm{N}$. and K. Sanamyan in the intertidal pool on the shore of Avacha Bay in the vicinity of Petropavlovsk-Kamchatsky about 15 years ago, but it was lost in the sand when they attempted to collect it. A few years latter, in 2004, several specimens were photographed underwater by N. Sanamyan near Starichkov Island, and one specimen was collected. It was successfully kept in aquarium for several months (Fig. 1C). Externally this beautiful specimen, with its pink tentacles, was not similar to other species of sea anemones known from the coasts of Kamchatka. Its morphology agreed with the features of Aulactinia, a genus difficult from taxonomic point of view and comprising many species (including most species formerly belonging to Bunodactis), but its specific assignment could not be determined at that time. In 2014 we were able to find many specimens of this species which were photographed underwater and collected. This material has allowed us to study details of the morphology, estimate a range of variations, and to describe a new species, $A u l$ actinia vladimiri sp.n.

The features of Aulactinia vladimiri sp.n. fit the definition of the genus Bunodactis as given by Carlgren (1949). The genus Bunodactis was synonymized with Aulactinia by Dunn et al. (1980) and since that time several species assignable to Bunodactis were described under the generic name Aulactinia. The taxonomic and nomenclatural problems around these two genera were discussed recently by Sanamyan et al. (2013), Spano et al. (2013) and Garese et. al. (2014). Spano et al. (2013) correctly pointed that Bunodactis was synonymized with Aulactinia only basing on the fact, that Carlgren (1949) placed the type species of Aulactinia to Bunodactis, and that the examination of type species of Aulactinia is required to clarify if two genera are synonyms. However, the matter appears to be more complicated. In particular, it is not quite clear if highly verrucose $B$. verrucosa (Pennant, 1777) (the type species of the genus) is congeneric with the species which have less prominent verrucae and lack marginal «pseudospherules» (including A. vancouverensis, A. stella, $A$. incubans, $A$. vladimiri sp.n., etc). England $(1987,1992)$ proposed to remove from Aulactinia all species having marginal spherules, including B. verrucosa, and place them to Gyractis. Obviously, the whole group of species, cur- 
Table 1. List of sea anemone species examined with GenBank accession numbers of their mtDNA sequences.

Таблица 1. Список исследованных видов актиний с номерами доступа в ГенБанке их митохондриальных последовательностей.

\begin{tabular}{|c|c|c|c|}
\hline Species and haplotype & 12S rRNA & 16S rRNA & COIII \\
\hline Aulactinia vladimiri sp.n. & KT310187 & KT310197 & KT310209 \\
\hline Aulactinia stella Pacific-1 & KT310188 & KT310198 & KT310210 \\
\hline A. stella Pacific-2 & KT310189 & KT310199 & KT310211 \\
\hline A. stella Pacific-3 & KT310190 & KT310200 & KT310212 \\
\hline A. stella Pacific-4 & KT310191 & KT310201 & KT310213 \\
\hline A. stella Pacific-5 & KT310192 & KT310202 & KT310214 \\
\hline A. stella White-Barents & KT310208 & JQ927444 & KT310207 \\
\hline Cnidopus japonicus Pacific-1 & KT310193 & KT310203 & KT310215 \\
\hline C. japonicus Pacific-2 & KT310194 & KT310204 & KT310215 \\
\hline C. japonicus Pacific-3 & KT310195 & KT310205 & KT310215 \\
\hline C. japonicus Pacific-4 & KT310196 & KT310206 & KT310215 \\
\hline
\end{tabular}

rently assigned to Bunodactis, Aulactinia, Gyractis and Anthopleura need to be revised until certain conclusions may be made. Pending such revision we prefer to keep more or less established in the literature the usage of the name Aulactinia as a valid genus.

\section{Material and methods}

Specimens of Aulactinia vladimiri sp.n. were observed and photographed underwater in their natural habitat to record colour, external appearance and position on substrate. The collected anemones ( 21 specimens) were fixed in seawater formalin, then some of them transferred to $70 \%$ ethanol for long-term storage. Small pieces of tissues cut from the pedal disk and limbus of six live specimens were placed directly to $96 \%$ ethanol for molecular study. The histological sections were prepared using isopropanolmineral oil method (see Sanamyan, Sanamyan, 2012). Size ranges of cnidae were measured on small pieces of macerated tissue according the method of Hand (1954) and the details of distribution of cnidae in different tissues were studied on histological sections stained by basic dyes (the method is described by Sanamyan et al., 2013). Cnidae terminology follows Weill (1934) and Carlgren (1949), but classification of p-mastigophores follows Schmidt (1969, $1972,1974)$ with the modification of den Har- tog (1995), for details see Sanamyan et al. (2012). Type material is stored at the Zoological Institute (ZIN) in St. Petersbourg, Russia and in Kamchatka Branch of Pacific Geographical Institute (KBPGI).

\section{Molecular techniques}

Data collection. Adult pedal disc tissues and juvenile polyp specimens were preserved in $96 \%$ ethanol prior to DNA extraction. The total DNA was extracted using Wizard SV Genomic DNA Purification System (Promega) following the manufacturer's protocol.

Mitochondrial gene fragments $12 \mathrm{~S}$ rRNA, 16S rRNA and COIII were amplified using published primers and protocols (Geller, Walton, 2001; Bocharova, 2015).

Sequence reaction was run using the BigDye v1.1 reagent kit (Applied Biosystems ${ }^{\odot}$ ). Purified and denatured reaction products were analyzed in the capillary molecular analyzer ABI PRISM 3130 (Applied Biosystems ${ }^{\odot}$ ) using POP7 gel polymer. In order to treat the chromatograms, a Sequencing Analysis 3.7 (Applied Biosystems $^{\odot}$ ) and Geneious 6.1.6 (http://www. geneious.com) were applied. After the treatment, the length of the 12S rRNA fragments was 663 nucleotides, $16 \mathrm{~S}$ rRNA -481 nucleotides, COIII - 485 nucleotides.

Forward and reverse sequences were assembled in and compared (via BLAST) against the 
nucleotide database of GenBank to determine whether the target locus and organism were sequenced rather than a symbiont or other contaminant. All assembled sequences have been deposited in GenBank (Table 1).

Data analysis. Sequences were manually edited and aligned using the Muscle algorithm with default parameters in Geneious 6.1.6. Complete and reduced alignments for each marker were analyzed separately and as a concatenated dataset in MEGA 6.0 (Tamura et al., 2013).

We conducted several analytical methods of phylogenetic reconstruction. Phylogenetic analyses [Maximum Likelihood (ML), Neighbor Joining (NJ), Minimum Evolution (ME), and Maximum Parsimony(MP)] were performed using Tamura 3-parameter model in MEGA 6.0. The presented bootstrap values were calculated for (1) ML: Nearest-Neighbor-Interchange heuristic method, Maximum Parsimony initial tree, very strong branch swap filter, 1000 replicates; (2) NJ: 1000 replicates; (3) ME: Close-Neighbor-Interchange heuristic method, NeighborJoining initial tree, search level — 1, 1000 replicates; (4) MP: MP Search Method - Maxmini Branch \& bound, 1000 replicates. Maximum Parsimony method was used to find the phylogram in Fig. 6.

Evolutionary analyses (Between Group Mean Distance) was conducted using the Maximum Composite Likelihood model in MEGA 6.0. Standard error estimate was obtained by a bootstrap procedure (500 replicates). Codon positions included were $1 \mathrm{st}+2 \mathrm{nd}+3 \mathrm{rd}+$ Noncoding. All positions containing gaps and missing data were eliminated.

\section{Taxonomy}

Order Actiniaria

Family Actiniidae

Aulactinia vladimiri sp.n.

Table 2; Figs. 1-5.

Aulactinia sp. Sanamyan, Sanamyan, 2010: 217.

MATERIAL EXAMINED. Holotype: ZIN No.11649, East Kamchatka, Avacha Bay, Mayachny Point, $52^{\circ} 53.219^{\prime} \mathrm{N}, 158^{\circ} 41.755^{\prime} \mathrm{E}, 7 \mathrm{~m}, \mathrm{t}=2^{\circ} \mathrm{C}, 11.07 .2014$, one specimen (Fig. 1E). Paratypes: ZIN No.11650, East Kamchatka, Avacha Bay, Mayachny Point, $52^{\circ} 53.219^{\prime} \mathrm{N}$, $158^{\circ} 41.755^{\prime} \mathrm{E}, 7 \mathrm{~m}, \mathrm{t}=2^{\circ} \mathrm{C}, 11.07 .2014$, two specimens; ZIN No.11651, same data, three specimens; KBPGI 459/ 4, same data, one specimen; KBPGI 460/5, same data, two specimens; KBPGI 461/6-464/9, Mayachny Point, $52^{\circ} 53.224^{\prime} \mathrm{N}, 158^{\circ} 41.729^{\prime} \mathrm{E}, 7-9 \mathrm{~m}, \mathrm{t}=7-10^{\circ} \mathrm{C}, 29.07$. 2014, four specimens; KBPGI 465/10-470/15, $52^{\circ} 53$. $212^{\prime} \mathrm{N}, 158^{\circ} 41.780^{\prime} \mathrm{E}, 5-8 \mathrm{~m}, \mathrm{t}=4^{\circ} \mathrm{C}, 5.06 .2014$, six specimens; KBPGI 471/16, Avacha Bay, Mayachny Point, 7 m, 12.09.2007, one specimen; KBPGI 472/17, Avacha Gulf, Starichkov Island, $6 \mathrm{~m}, 31.08 .2004$, one specimen. All specimens collected by N. Sanamyan.

ADDITIONAL MATERIAL EXAMINED. Cnidopus japonicus (Verrill, 1869) - haplotype 1 (Pacific-1): East Kamchatka, Avacha Gulf, Listvenichnaya Bay, Piramidny Point, $52^{\circ} 22.881^{\prime} \mathrm{N}, 158^{\circ} 34.419^{\prime} \mathrm{E}, 15 \mathrm{~m}, \mathrm{t}=1^{\circ} \mathrm{C}, 16.07$. 2014, one specimen; haplotype 2 (Pacific-2): same data, one specimen; haplotype 3 (Pacific-3): KBPGI 448/44, East Kamchatka, Avacha Gulf, Viluchinskaya Bay, $52^{\circ} 36$. $859^{\prime} \mathrm{N}, 158^{\circ} 29.638^{\prime} \mathrm{E}, 19 \mathrm{~m}, \mathrm{t}=1^{\circ} \mathrm{C}, 24.07 .2014$, one specimen; East Kamchatka, Avacha Gulf, three specimens; haplotype 4 (Pacific-4): East Kamchatka, Avacha Gulf, two specimens.

DESCRIPTION. External structure. The specimens of the species are rather small, the tentacular crown of fully expanded living specimens is up to 3-4 cm in diameter. Formalinpreserved specimens are $12-25 \mathrm{~mm}$ in diameter and $8-21 \mathrm{~mm}$ in height. The circular and strongly adhesive pedal disk is about the same diameter as column. The column is cylindrical and short, red or pink, paler proximally. Small adhesive verrucae, to many of which gravel particles and broken shells are attached, are arranged in 48 longitudinal rows on the distal (upper) half of the column but not present in proximal part of the body. Verrucae are marked by bright white spots contrasting with the colour of the column and well visible on live specimens (Figs 1C, D; 2A). There are no special marginal structures although on strongly contracted specimens most distal parts of intermesenterial spaces on the margin may became inflated (Fig. 1E). There is a deep fosse and a short capitulum.

The oral disk is circular and flat. The tentacles, up to 48 in number, are arranged hexamerously in four cycles on the outer part of the oral disk. The tentacles are rather straight, tapering, blunt pointed, all of about the same size, their length usually not exceeding the diameter of oral disk (Fig. 1A, B). The background colour of the oral disk is grayish pink. Mesenterial insertions on the oral disk are marked by deep 

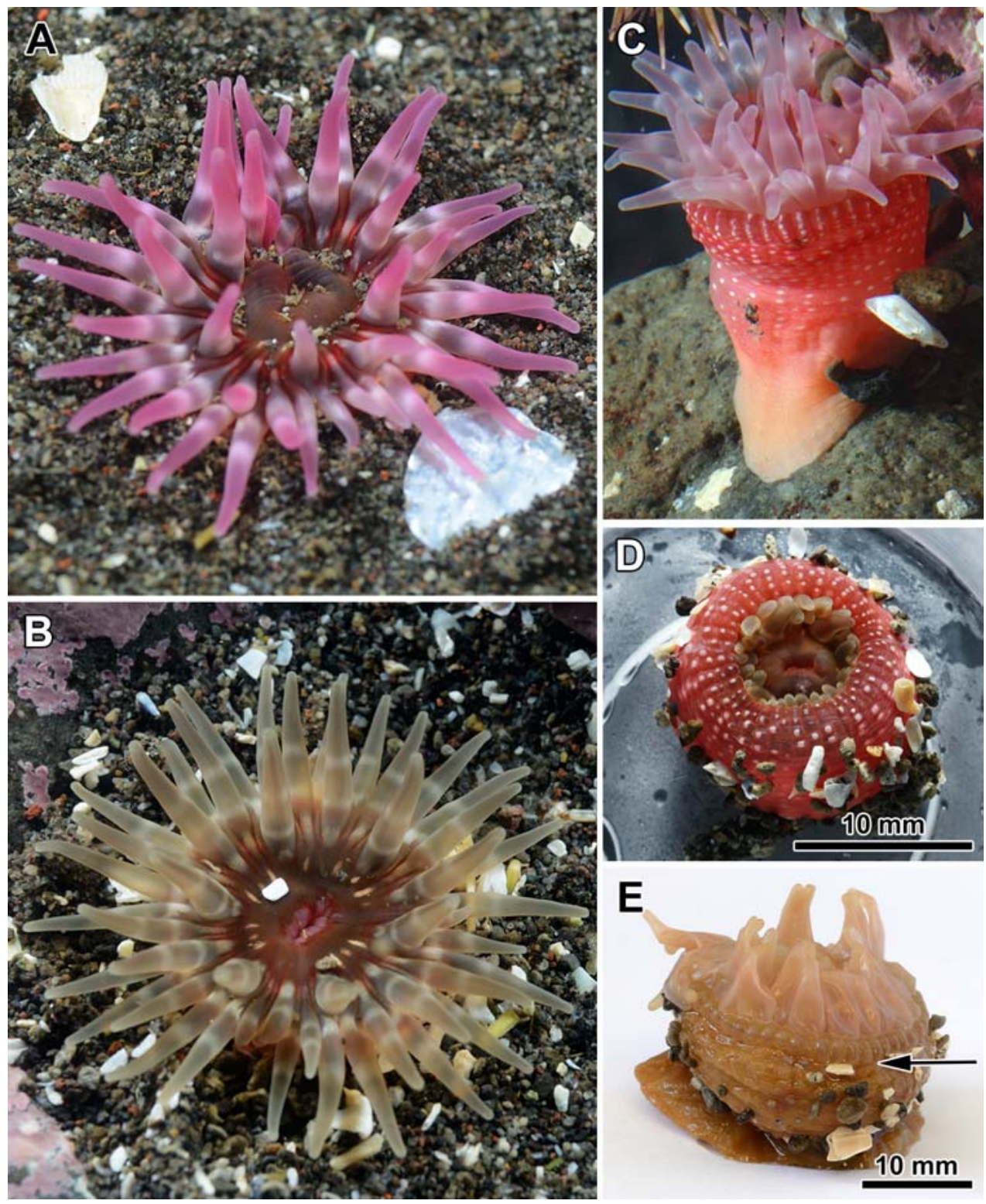

Fig. 1. Aulactinia vladimiri sp.n. A-B - live specimens in natural habitat, two colour morphs; C - side view of the specimen with pink tentacles (in aquarium), note white spots marking verrucae which disappear on the proximal part of the column (KBPGI 472/17); D - contracted live specimen with grey tentacles, the colour of the column is of the same, as in the specimens with pink tentacles (red with white verrucae), it has no brood chamber (KBPGI 464/9); E - the holotype, preserved (ZIN 11649), arrow indicate the furrow of the brood chamber.

Рис. 1. Aulactinia vladimiri sp.n. А-B - живые экземпляры в естественной среде обитания, две цветовые формы; C - вид сбоку экземпляра с розовыми щупальцами, белые точки маркируют верруки, которых нет в нижней части колюмна (KBPGI 472/17); D - сжавшийся живой экземпляр с серыми щупальцами, цвет колюмна у него такой же, как и у экземпляров с розовыми щупальцами (красный с белыми бородавками), этот экземпляр не имеет выводковой камеры (KBPGI 464/9); E голотип, фиксированный (ZIN 11649), стрелка указывает на борозду, ведущую в выводковую камеру. 
red lines. White short stripes or dots over endocoels of third order are arranged in a circle in half way between the mouth and tentacles of many specimens. In most specimens the tentacles are bright pink with two transverse whitish bands on their oral and lateral sides; the pink colour is more saturated on distal half of the tentacles (Fig. 1A). Among several tens of typically coloured specimens we observed two with the grayish tentacles (Fig. 1B). The column of these specimens was of the same red colour (Fig. 1D) as in the specimens with pink tentacles and the colour pattern on the disk was the same.

Internal structure. Marginal endodermal sphincter muscle is about $0.9-2 \mathrm{~mm}$ in greatest diameter on transverse section, circumscribed, oval, pinnate, with very thin central lamella (Fig. 3B) which sometimes is not well defined (Fig. 3C), attached to body wall in the fosse (Fig. 3A). The central lamella divides the sphincter into two unequal halves: the mesogloeal processes on the side faced to the bottom of the fosse are two or three times longer than those on the opposite side of the central lamella. Radial muscles of oral disk and longitudinal muscles of tentacles are ectodermal (Fig. 3D), the former are poorly developed. Circular endodermal columnar muscles well developed on the whole column and not interrupted on verrucae (Fig. $3 F)$. Actinopharynx has two deep siphonoglyphs supported by directives.

The mesenteries are arranged hexamerously in three cycles: $6+6+12$. The number of mesenteries is the same along the whole length of column. All mesenteries are perfect (those of third cycle are attached to actinopharynx in its distal part). The mesenteries of all cycles have large oral $(1-2 \mathrm{~mm})$ and marginal $(2-3 \mathrm{~mm})$ stomata. Retractor muscles on all mesenteries are strong, diffuse to restricted, with numerous heavily branched mesogloeal processes (Fig.
4A). Parietobasilar muscles form free flap better developed on the mesenteries of the first cycle. Basilar muscles well developed (Fig. $3 \mathrm{E})$. The mesenteries of the first and the second cycles are fertile.

Sexes are separated, among 13 sectioned specimens 11 were females, one was a male and one specimen was sterile. The developing ova are very large, up to $1.8-2.2 \mathrm{~mm}$ in diameter, bright red on fresh material (Fig. 4B). In many female specimens (including the holotype, Fig. 1E) the ova are incubated in a brood chamber formed by deep circumferential fold on the distal (upper) part of the column (Fig. 2B-D). The ova lie in the bottom of this fold, in two rows, each in an individual thin-walled pouch (Fig. 2C). In all examined specimens the brood chamber is tightly closed, its walls are firmly pressed to each other and in live expanded specimens the presence of the brood chamber cannot be revealed. On the contracted specimens the brood chamber (to be more precise the entrance to the brood chamber) may be visible as a circumferential furrow on the upper column just below the margin (Fig. 2A). There are no eggs attached to column wall outside from the brood chamber. The eggs in the brood chamber are rich of yolk and are not ciliated. In all examined specimens only such large eggs were found, none of the specimens had developing larvae in the coelenteron or attached to the column.

Spermatozoa are bilaterally symmetrical and blunt headed, the size of the head is $3-3.5 \times 1.5-$ 2 microns (Fig. 4C).

Cnidom. Cnidom includes spirocysts, basitrichs, p-mastigophores A, p-mastigophores B1 (see Table 2 and Fig. 5). Small rare columnar basitrichs (Fig. 5B) occur mostly on the distal (upper) part of column on verrucae. The basitrichs in the tips of the tentacles are very

Fig. 2. Aulactinia vladimiri sp.n. A - contracted live specimen with the brood chamber (KBPGI 461/6), note the circumferential furrow on the upper part of column (arrow); B - longitudinal histological section of upper part of column to show the brood chamber (KBPGI 462/7); C-D — preserved specimen sectioned longitudinally (KBPGI 461/6), note that the brood chamber is formed by a deep fold of the wall of column and the eggs are incubated in the thin-walled pouches in the bottom of this fold.

Abbreviations: od — oral disk; ov — ova; $\mathrm{s}$ - marginal sphincter; $\mathrm{t}$ - tentacles. Arrows indicate entrance into the brood chamber. 

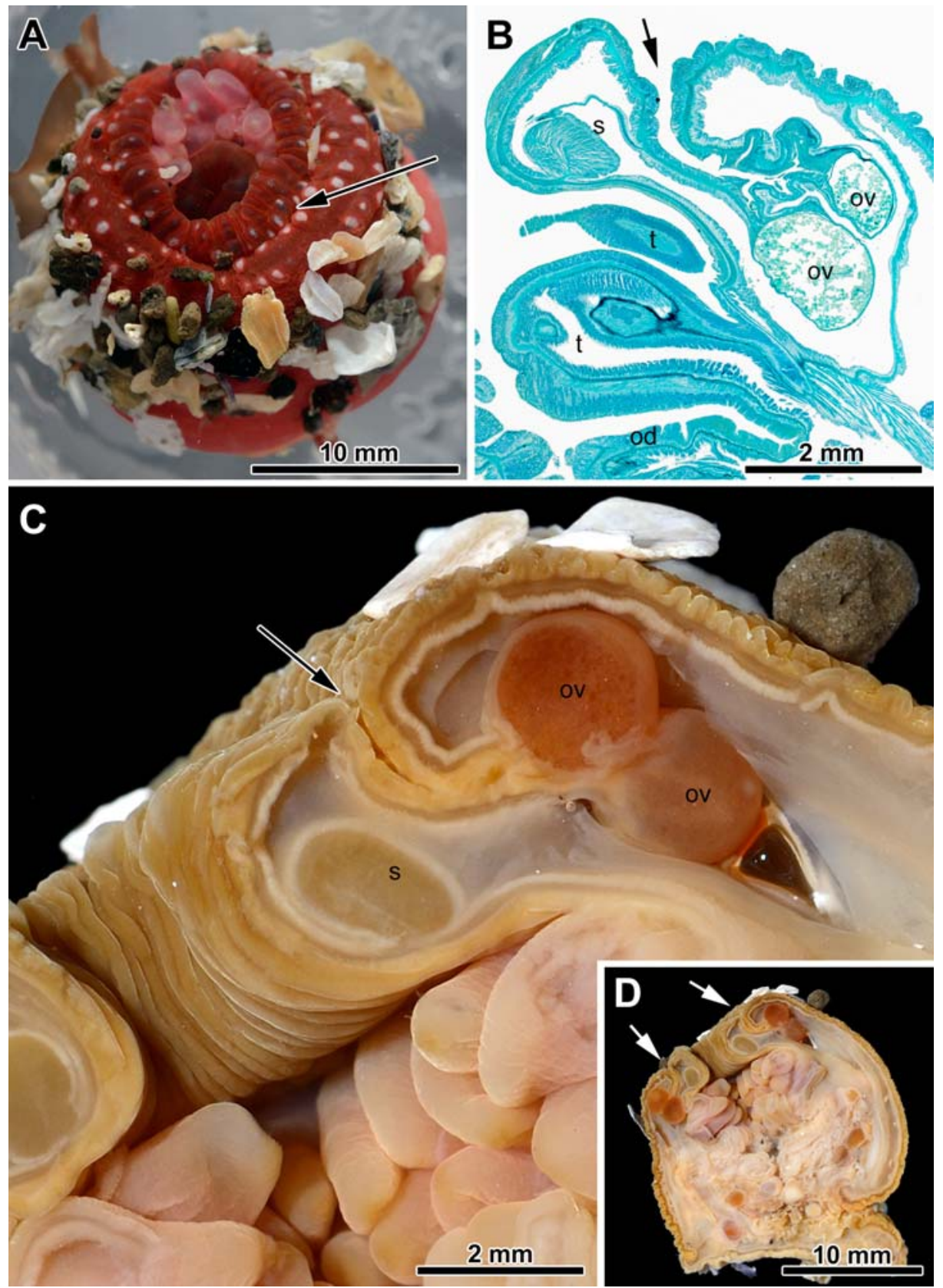

Рис. 2. Aulactinia vladimiri sp.n. А — сжавшийся живой экземпляр с выводковой камерой (KBPGI 461/ 6), видна круговая борозда в верхней части колюмна (обозначена стрелкой); В — продольный гистологический срез через верхнюю часть колюмна, показывающий выводковую камеру (KBPGI 462/7); C-D - фиксированный экземпляр, разрезанный вдоль (KBPGI 461/6), видно, что выводковая камера сформирована глубокой складкой стенки колюмна, и яйца инкубируются в тонкостенных карманах на дне этой складки.

Сокращения: od — оральный диск; ov — яйца; $\mathrm{s}$ - маргинальный сфинктер; $\mathrm{t}$ - щупальца. Стрелками обозначен вход в выводковую камеру. 


\section{A}
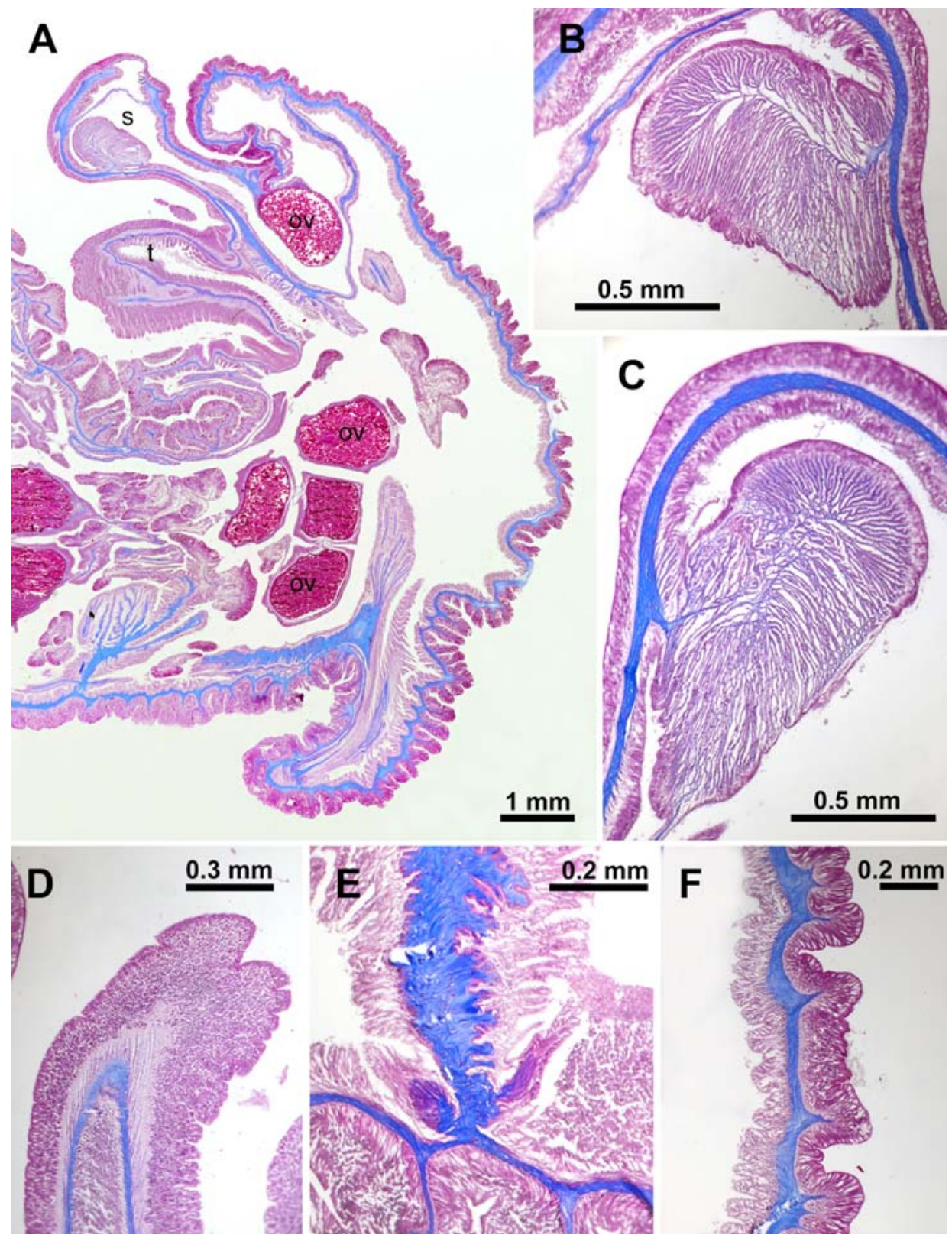

Fig. 3. Aulactinia vladimiri sp.n., histological sections (KBPGI 462/7). A - longitudinal section of the whole specimen; B-C - the sphincter muscle, enlarged; D - oblique section of the tentacle, longitudinal ectodermal muscles are visible; E - basilar muscles; F - longitudinal section of verruca on the column. Abbreviations: ov - ova; $\mathrm{s}$ - marginal sphincter; $\mathrm{t}$ - tentacles.

Рис. 3. Aulactinia vladimiri sp.n., гистологические срезы (KBPGI 462/7). А - продольный срез через весь экземпляр; В-C - сфинктер, увеличено; D - косой срез через щупальце, видны продольные эктодермальные мускулы; Е - базилярные мускулы; F - продольный срез через бородавку на колюмне.

Сокращения: ov — яйца; s — маргинальный сфинктер; $\mathrm{t}$ - щупальца. 


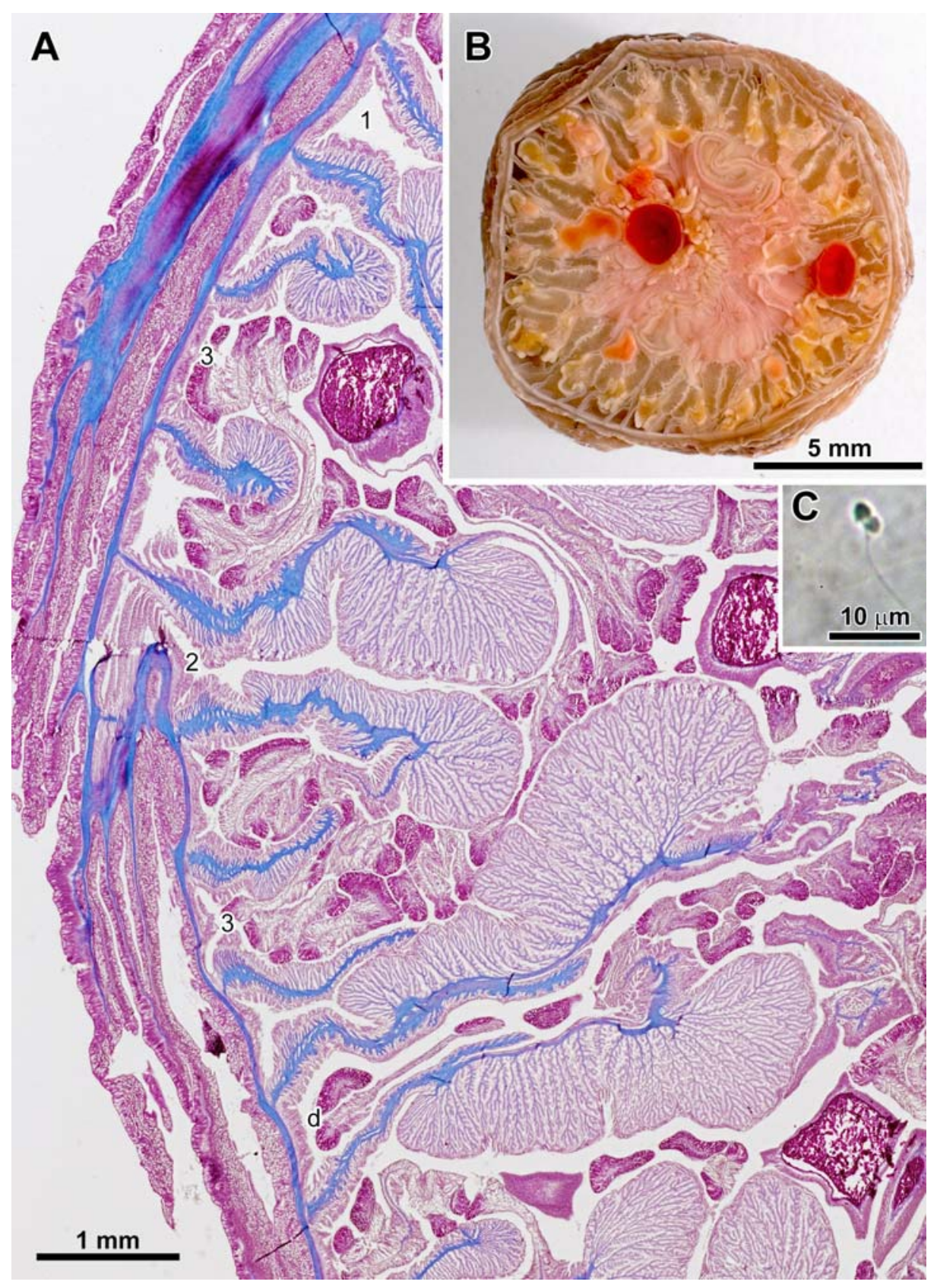

Fig. 4. Aulactinia vladimiri sp.n. A - transverse section of proximal part of column (below actinopharynx) to show arrangement and musculature of the mesenteries (KBPGI 462/7); B - transverse sections of freshly preserved specimen (KBPGI 472/17), note large bright-red ova; C - spermatozoon.

Abbreviations: $\mathrm{d}$ - directives. The numbers indicate the cycles of mesenterial pairs.

Рис. 4. Aulactinia vladimiri sp.n. А - поперечный срез через проксимальную часть колюма (ниже глотки), показывающий организацию циклов мезентериев и их мускулатуру (KBPGI 462/7); В поперечный срез недавно зафиксированного экземпляра (KBPGI 472/17), видны большие яркокрасные яйца; С - сперматозоид.

Сокращения: $\mathrm{d}$ - направляющие мезентерии. Цифрами обозначены номера циклов пар мезентериев. 
Table 2. Size ranges (length $\times$ width, in microns) and distribution of cnidae of Aulactinia vladimiri sp.n.

Letters in brackets correspond to letters in Fig. 5. "N" - ratio of number of specimens in which each cnidae was found to number of specimens examined.

Таблица 2. Размеры (длина $\times$ ширина, в микронах) и распределение стрекательных капсул Aulactinia vladimiri sp.n. Буквы в скобках соответствуют буквам на рис. 5. "N" - отношение количества экземпляров, в которых данный тип стрекательных капсул был найден, к количеству исследованных экземпляров.

\begin{tabular}{llccc}
\hline Body region & \multicolumn{1}{c}{ Cnidae } & $\begin{array}{c}\text { Size ranges } \\
\text { holotype }(\mu \mathrm{m})\end{array}$ & $\begin{array}{c}\text { Size ranges all } \\
\text { specimens }(\mu \mathrm{m})\end{array}$ & $\mathrm{N}$ \\
\hline Pedal disc & (A) basitrichs (few) & $20-30 \times 2-3$ & $20-30 \times 2-3$ & $2 / 2$ \\
\hline \multirow{2}{*}{ Column } & (B) basitrichs (rare) & $10-13 \times 1.5-2.5$ & $10-14 \times 1.5-2.5$ & $6 / 6$ \\
& $(\mathrm{C})$ basitrichs (common) & $14-25 \times 2-3$ & $14-25 \times 2-3$ & $6 / 6$ \\
\hline \multirow{2}{*}{ Tentacles } & (D) spirocysts (numerous) & $19-35 \times 2-3.5$ & $19-36 \times 1.5-3.5$ & $5 / 5$ \\
& (E) basitrichs (numerous) & $19-30 \times 2-3$ & $19-30 \times 2-3.5$ & $5 / 5$ \\
\hline \multirow{2}{*}{ Actinopharynx } & (F) basitrichs (common) & $25-34 \times 3-4$ & $24-35 \times 3-4.5$ & $5 / 5$ \\
& (G) p-mastigophores A (few) & $23-30 \times 5-6.5$ & $21-32 \times 4.5-6.5$ & $5 / 5$ \\
\hline \multirow{3}{*}{ Filaments } & (H) basitrichs (common) & $15-20 \times 2-3$ & $14-20 \times 2-3$ & $5 / 5$ \\
& (I) basitrichs (common) & $26-36 \times 2-3.5$ & $24-36 \times 2-3.5$ & $5 / 5$ \\
& (J) p-mastigophores B1 & $25-42 \times 4.5-5$ & $25-43 \times 3.5-6$ & $5 / 5$ \\
& (common) & & & \\
\hline Endoderm & (K) p-mastigophores A & $24-30 \times 4.5-6.5$ & $21-32 \times 4-7$ & $5 / 5$ \\
\hline
\end{tabular}

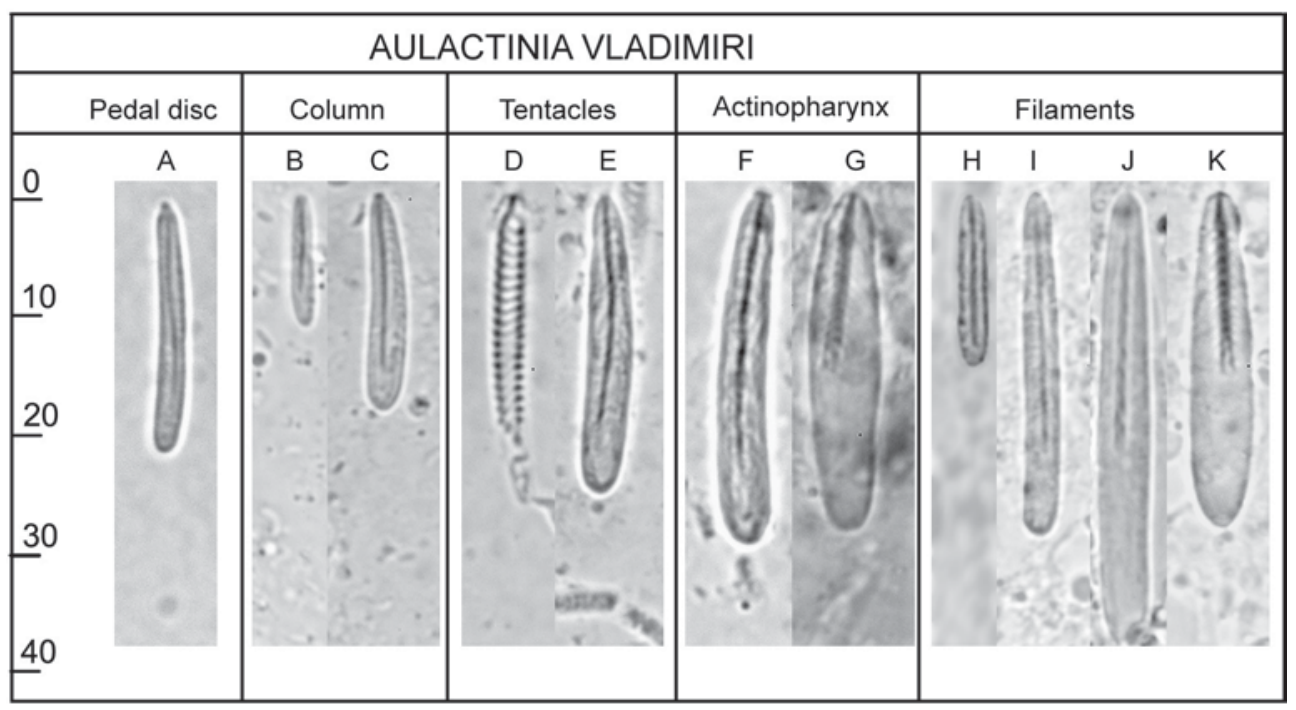

Fig. 5. Aulactinia vladimiri sp.n., cnidom (see Table 2 for size ranges).

Рис. 5. Aulactinia vladimiri sp.n., книдом (размеры указаны в табл. 2).

numerous (more numerous than spirocysts) and crowded, but become sparser toward the bases of the tentacles.

HABITAT. All recorded specimens of Aulactinia vladimiri sp.n. were buried in a coarse sand or gravel with the pedal disk attached to buried stones or rock. Only the oral disk with the tentacles is visible on the surface. The specimens may occur solitary or in small groups. The species was observed from intertidal zone to a 
depth of about $9 \mathrm{~m}$. It has patchy distribution and is rather rare in the studied region (Avacha Bay, east coast of Kamchatka).

ETYMOLOGY. The species is named after Vladimir Timoshenko who was in command of the boat "Chaika" and helped a lot in our field work.

REMARKS. Aulactinia vladimiri sp.n. is the second species of Aulactinia recorded from the Pacific coasts of Kamchatka (Sanamyan, Sanamyan, 2009, 2010). Aulactinia stella (Verrill, 1864), the only species of Aulactinia known previously in this region, is larger, has more numerous (up to 150) tentacles and more than three (up to five) cycles of mesenteries. These two species may occur together but they cannot be confused, in particular none of the several colour morph of $A$. stella has such bright pink tentacles as in $A$. vladimiri sp.n. Aulactinia stella is an internal brooder, the larvae are brooded in the coelenteron and may attain rather large size with developed tentacles and mesenteries (Verrill, 1922; Sanamyan, Sanamyan, 2009). Aulactinia vladimiri sp.n., in contrast, is an external brooder, the eggs are incubated on the ectodermal (the outer) side of the column, in the bottom of the tightly closed brood chamber formed by the invagination of the body wall. Two species of Aulactinia known from NE Pacific, A. incubans and A. vancouverensis, differ from the $A$. vladimiri sp.n. in the same way, they have more mesenteries and tentacles, different colouration and both are internal brooders. Cnidom of A. stella, A. incubans and A. vancouverensis includes holotrichs (at limbus and outer tentacles), while in A. vladimiri sp.n. holotrichs were not found.

Epiactis lewisi Carlgren, 1940 has a very similar brood chamber, formed by deep circular invagination of column "fairly close to the sphincter" (Carlgren, 1940, p.23). (Compare fig. 2b in Carlgren, 1940 and Fig. 2B in the present work). The description of this species is based on one specimen from Chukchi Sea. Its size is comparable with the size of preserved specimens of Aulactinia vladimiri sp.n., but $E$. lewisi has only 24 tentacles and 12 mesenteries, and its column is smooth.
Larson, Daly (2015) recently discovered and described in details external circular sealed brood chamber in Cnidpous ritteri (Torrey, 1902). They tentatively synonymized Cnidopus with Epiactis, but pending more detailed discussion we prefer to continue treat it as a valid genus, see Sanamyan, Sanamyan (1998) for details. [When the current paper was in press we were informed that in their new paper (in press) Larson and Daly rejected validity of Cnidopus basing on molecular data]. Despite the presence of similar brood chamber Aulactinia vladimiri sp.n. cannot be confused with any species of Cnidopus or Epiactis, all members of which have no adhesive verrucae on column.

The correct attribution of large nematocysts in the filaments, called here p-mastigophores B1 (Fig. 5J), is not quite clear. In fired capsules the tubule appears to be isodiametric and in unfired the V-shaped notch is not always obvious. Similar capsules occur in the filaments of several actiniid genera (e.g. Aulactinia, Epiactis, Urticina, Cribrinopsis, Anthopleura, Bunodosoma). Sometimes they are recorded in the literature as basitrichs (e.g. Dunn et al., 1980; Fautin, Chia, 1986), but in other cases as pmastigophores (e.g. Hand, 1955; Hartog, 1987; Hauswaldt, Pearson, 1999; Yanagi, Daly, 2004; Sanamyan, Sanamyan, 2006; Sanamyan et al., 2013; Larson, Daly, 2015) or microbasic bmastigophores (e.g. Rodríguez, López-González, 2013). Despite the fact, that different authors attribute them to different categories, most probably these similarly looking cnidae from different species belong to one type - all these genera have almost the same composition of nematocysts types in the filaments (several, usually two, types of basitrichs, one type of pmastigophores A and a discussed here type with indistinct V-shaped notch in unfired capsule). Dunn et al. (1980: 2076) identified these capsules from the filaments of Aulactinia incubans as basitrichs, but noted that they "may be mistaken for microbasic p-mastigophores because heavy basal spines form V-shaped notch in unfired state, but butt is not dilated". In some Urticina and Cribrinopsis species (e.g. the species described in Sanamyan, Sanamyan, 2006) 


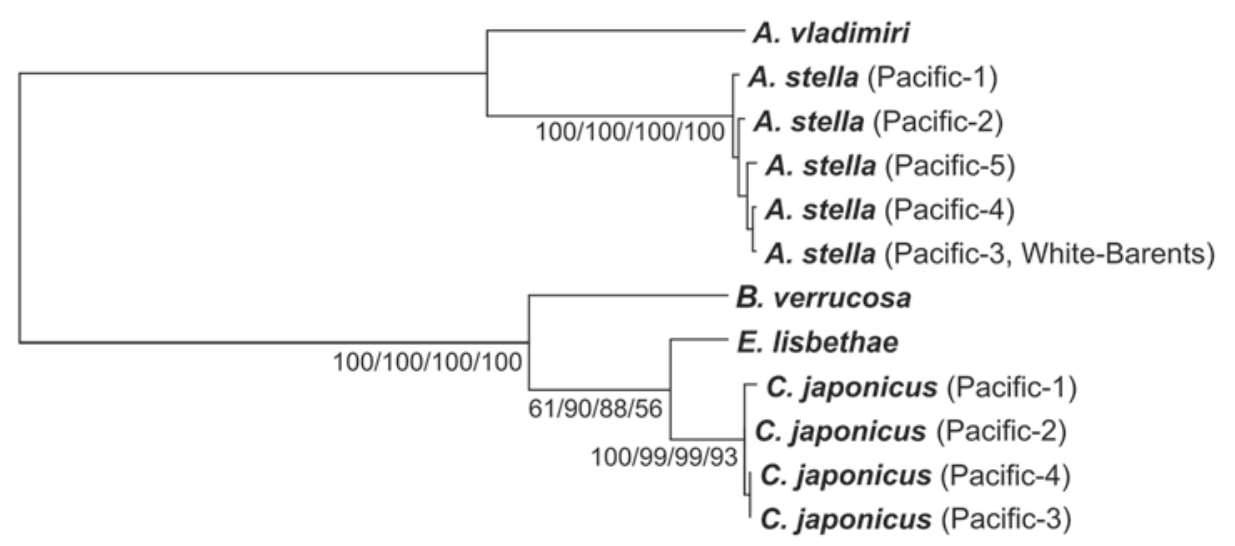

$\stackrel{\vdash}{20 \text { changes }}$
$\mathrm{ML} / \mathrm{NJ} / \mathrm{ME} / \mathrm{MP}$

Fig. 6. One of ten most parsimonious unrooted phylograms depicting the phylogenetic relationships for Aulactinia vladimiri sp.n., A. stella (Pacific-1-Pacific-5, White-Barents) and Cnidopus japonicus (Pacific1-Pacific-4) collected from the Pacific Ocean, Epiactis lisbethae (concatenated EU190727, EU190771, and GU473360) and Bunodactis verrucosa (concatenated EU190723, EU190766, and FJ489484) found in the nucleotide database of GenBank. Tree was reconstructed by Tamura 3-parameter model. Numbers on nodes represent bootstrap values calculated by Maximum Likelihood (left, Nearest-Neighbor-Interchange heuristic method, Maximum Parsimony initial tree, very strong branch swap filter, 1000 replicates), Neighbor Joining (left in the middle, 1000 replicates), Minimum Evolution (right in the middle, Close-Neighbor-Interchange heuristic method, Neighbor Joining initial tree, search level - 1, 1000 replicates), and Maximum Parsimony (right, Search Method - Max-mini Branch \& bound, 1000 replicates).

Рис. 6. Одна из десяти неукорененных филограмм, построенная методом максимальной экономии и изображающая филогенетические отношения Aulactinia vladimiri sp.n., A. stella (Pacific-1-Pacific-5, White-Barents) и Cnidopus japonicus (Pacific-1-Pacific-4) из Тихого океана, Epiactis lisbethae (объединенные последовательности EU190727, EU190771 и GU473360) и Bunodactis verrucosa (объединенные последовательности EU190723, EU190766 и FJ489484) из ГенБанка. Дерево построено с помощью 3-параметрической модели Тамуры. Номера в узлах показывают значения бутстрэпа, посчитанные методами максимального правдоподобия (слева, эвристический метод обмена ближайших соседей, исходное дерево по методу максимальной экономии, очень сильный фильтр при обмене ветвями, 1000 повторов), ближайших соседей (слева посередине, 1000 повторов), минимальной эволюции (справа посередине, эвристический метод обмена ближайших соседей, исходное дерево по методу ближайших соседей, уровень поиска - 1, 1000 повторов) и максимальной экономии (справа, метод поиска - максимальных и минимальных ветвей и границ, 1000 повторов).

fired capsules of this type have more or less well defined shaft and we had no doubt in assigning them to p-mastigophores. Attribution of these cnida to p-mastigophores in $U$. candenstina Sanamyan, Sanamyan, McDaniel, 2013 and Aulactinia vancouverensis Sanamyan, Sanamyan, McDaniel, 2013 is less obvious (see discussion in Sanamyan et al., 2013), but it is clear that they belong to the same type as those in other species of Urticina and other above listed genera. It seems that at the current state of knowledge these cnidae cannot be surely attributed to ba- sitrichs or to p-mastigophores. In the current paper we follow Hartog (1987) and other authors who recorded them as p-mastigophores B1.

RESULTS OF MOLECULAR ANALYSIS. Only one mitochondrial haplotype was detected among six studied Aulactinia vladimiri sp.n. specimens. The comparison of available mitochondrial sequences was provided for species of genus Aulactinia, A. vladimiri sp.n. and $A$. stella, type species of the genus Bunodactis, $B$. verrucosa, and two other species with external brooding: Epiactis lisbethae Fautin et Chia, 
1986 and Cnidopus japonicus (Verrill, 1869). For phylogenetic reconstruction of concatenated mitochondrial fragments (12S rRNA, 16S rRNA, COIII) six haplotypes (Pacific-1-Pacific-5, White-Barents) of A. stella were used from the previous paper (Bocharova, 2015), four haplotypes (Pacific-1-Pacific-4) of C. japonicus were newly obtained in this work (specimens from Kamchatka), and the haplotypes of $E$. lisbethae (concatenated sequences EU190727, EU190771, and GU473360) and $B$. verrucosa (concatenated sequences EU190723, EU190766, and FJ489484) were found in the nucleotide database of GenBank.

Ten (equally) most parsimonius trees were obtained with a Branch and Bound search (MEGA 6.0). The topology of resulted unrooted phylograms is identical, thus only one of them is presented in Fig. 6. Different bootstrap values for $\mathrm{ML} / \mathrm{NJ} / \mathrm{ME} / \mathrm{MP}$ were calculated and Tamura 3-parameter model was used for ML/ NJ/ME. A phylogenetic analysis shows that $A$. stella haplotypes and $A$. vladimiri form separate clade, but these two species are clearly distinct (Between Group Mean Distance — 0.062, Standart Error - 0.011). Another major clade found by the analysis with $100 / 100 / 100 / 100 \%$ bootstrap support includes $B$. verrucosa and the grouping of E. lisbethae and $C$. japonicus haplotypes (Fig. 6).

\section{ACKNOWLEDGMENTS}

We are grateful to the crew of the boats "Chaika" for the help during dives under sometimes difficult conditions.

\section{References}

Bocharova E.S. 2015. Reproductive biology and genetic diversity of the sea anemone Aulactinia stella (Verril, 1864) // Hydrobiologia. Vol.759. No.1. P.27-38.

Carlgren O. 1940. Actiniaria from Alaska and Arctic waters // Journal of the Washington Academy of Sciences. Vol.30. No.1. P.21-27.

Carlgren O. 1949. A survey of the Ptychodactiaria, Corallimorpharia and Actiniaria // Kungliga Svenska Vetenskapsakadamiens Handlingar. Vol.1. P.1-121.

Dunn D.F., Chia F., Levine R. 1980. Nomenclature of Aulactinia (=Bunodactis), with description of Aulactinia incubans n.sp. (Coelenterata: Actiniaria), an internally brooding sea anemone from Puget Sound // Canadian Journal of Zoology. Vol.58. P.2071-2080. England K.W. 1987. Certain Actiniaria (Cnidaria, Anthozoa) from the Red Sea and tropical Indo-Pacific Ocean // Bulletin of the British Museum (Natural History). Zoology. Vol.53. No.4. P.205-292.

England K.W. 1992. Actiniaria (Cnidaria: Anthozoa) from Hong Kong with additional data on similar species from Aden, Bahrain and Singapore // B. Morton (ed.). Proceedings of the Fourth International Marine Biological Workshop: The Marine Flora and Fauna of Hong Kong and the Southern China. Hong Kong, 1129 April 1989. Hong Kong: Hong Kong University Press. P.49-95.

Fautin D.G., Chia F.S. 1986. Revision of sea anemone genus Epiactis (Coelenterata: Actiniaria) on the Pacific coast of North America, with descriptions of two new brooding species // Canadian Journal of Zoology. Vol.64. P.1665-1674.

Garese A., Longo M.V., Martin J.P., Acuña F.H. 2014. The sea anemone Bunodactis octoradiata (Anthozoa: Actiniaria) from southern Patagonia: morphological study and new records // Zoologia. Vol.31. No.5. P.475-481.

Geller J. B., E. Walton D. 2001. Breaking up and getting together: evolution of symbiosis and cloning by fission in sea anemones (Genus Anthopleura) // Evolution. Vol.55. P.1781-1794.

Hand C. 1954. The sea anemones of Central California, part 1. The Corallimorpharian and Athenarian anemones // Wasmann Journal of Biology. Vol.12. P.345375.

Hand C. 1955. The sea anemones of Central California, Part 2. The Endomyarian and Mesomyarian anemones // The Wasmann Journal of Biology. Vol.13. No.1. P.37-99.

Hartog J.C., den 1987. A redescription of the sea anemone Bunodosoma biscayensis (Fisher, 1874) (Actiniaria, Actiniidae) // Zoologische Mededelingen, Leiden. Vol.61. No.36. P.533-559.

Hartog J.C., den. 1995. The genus Telmatactis Gravier, 1916 (Actiniaria: Isophellidae) in Greece and the eastern Mediterranean // Zoologische Mededelingen, Leiden. Vol.69. No.14. P.153-176.

Hauswaldt J.S., Pearson K.E. 1999. Urticina mcpeaki, a new species of sea anemone (Anthozoa: Actiniaria: Actiniidae) from the North American Pacific coast // Proceedings of the Biological Society of Washington. Vol.112. No.4. P.652-660.

Larson P.G., Daly M. 2015. 'Putting names with faces': a description of Epiactis handi sp. nov helps to resolve taxonomic confusion in species of the sea anemone Epiactis (Actiniaria, Actiniidae) // Journal of the Marine Biological Association of the United Kingdom. Vol.93. No.3. P.913-928.

Rodríguez E., López-González P.J. 2013. New records of Antarctic and Sub-Antarctic sea anemones (Cnidaria, Anthozoa, Actiniaria and Corallimorpharia) from the Weddell Sea, Antarctic Peninsula, and Scotia Arc // Zootaxa. Vol.3624. No.1. P.1-100. 
Sanamyan N., Sanamyan K. 1998. Some Actiniaria from the Commander Islands (Cnidaria: Anthozoa) // Zoosystematica Rossica. Vol.7. P.1-8.

Sanamyan N., Sanamyan K. 2006. The genera Urticina and Cribrinopsis (Anthozoa: Actiniaria) from the north-western Pacific // Journal of Natural History. Vol.40. No.7-8. P.359-393.

Sanamyan N.P., Sanamyan K.E. 2009. Shallow water anemones (Cnidaria: Actiniaria) from south-eastern coast of Kamchatka // Invertebrate Zoology. Vol.5 (for 2008). No.2. P.155-172.

Sanamyan N.P., Sanamyan K.E. 2010 (for 2009). [Anthozoans (Cnidaria: Anthozoa) found at the coasts of Starichkov Island] // Sanamyan K.E., Sanamyan N.P., Tokranov A.M., Cherniagina O.A. (eds.). Biota of Starichkov Island and adjacent waters of Avacha Gulf. Proceedings of Kamchatka Branch of Pacific Institute of Geography, Far Eastern Division, Russian Academy of Sciences. Petropavlovsk-Kamchatskii: Kamchatpress. No.8. P.208-226 [in Russian].

Sanamyan N.P., Sanamyan K.E. 2012. [Isopropanol mineral oil method in histology] // Bugaev F.V., Tokranov A.M., Cherniagina O.A. (eds.). Conservation of biodiversity of Kamchatka and coastal waters: materials of XIII international scientific conference, dedicated to the 75th anniversary of S.A. Dyrenkov's birthday. Petropavlovsk-Kamchatsky: Kamchatpress. P.155-159 [in Russian].

Sanamyan N., Sanamyan K., McDaniel N. 2013. Two new shallow water sea anemones of the family Actiniidae (Cnidaria: Anthozoa: Actiniaria) from British Columbia (NE Pacific)// Invertebrate Zoology. Vol.10. No.2. P.199-216.

Sanamyan N., Sanamyan K., Tabachnick K. 2012. The first species of Actiniaria, Spongiactis japonica gen.n., sp.n. (Cnidaria: Anthozoa) an obligate symbiont of a glass sponge // Invertebrate Zoology. Vol.9. No.2. P.127-141.
Schmidt H. 1969. Die Nesselkapseln der Aktinien und ihre differentialdiagnostische Bedeutung // Helgoländer Wissenschaftliche Meeresuntersuchungen. Bd.19. S.284-317.

Schmidt H. 1972. Die Nesselkapseln der Anthozoen und ihre Bedeutung für die phylogenetische Systematik // Helgoländer Wissenschaftliche Meeresuntersuchungen. Bd.23. S.422-458.

Schmidt H. 1974. On evolution in the Anthozoa // Proceeding of the Second International Coral Reef Symposium 1. Great Barrier Reef Committee, Brisbane, October, 1974. P. 533-560.

Spano C., Rozbaczylo N., Haussermann V., Bravo R. 2013. Redescription of the sea anemones Anthopleura hermaphroditica and Bunodactis hermafroditica (Cnidaria: Anthozoa: Actiniaria) from Chile // Revista de Biologia Marina y Oceanografia. Vol.48. No.3. P.521-534.

Tamura K., Stecher G., Peterson D., Filipski A., Kumar S. 2013. MEGA6: Molecular Evolutionary Genetics Analysis Version 6.0 // Molecular Biology and Evolution. Vol.30. P.2725-2729.

Verrill A.E. 1922. The Actiniaria of the Canadian Arctic Expeditions, with notes on interesting species from Hudson Bay and other Canadian localities // Report on the Canadian Arctic Expedition 1913-1918. Vol.8. Part G. P.89-164.

Weill R. 1934. Contribution a l'Étude des Cnidaires et de leurs Nématocystes. Paris: Les Presses Universitaires de France. 701 p.

Yanagi K., Daly M. 2004. The hermaphroditic sea anemone Anthopleura atodai n. sp. (Anthozoa: Actiniaria: Actiniidae) from Japan, with a redescription of $A$. hermaphroditica // Proceedings of the Biological Society of Washington. Vol.117. P.408-422.

Responsible editor A.Yu. Sinev 